\title{
THE LEGAL REGIME OF THE LIABILITY OF THE ADMINISTRATORS OF THE COMMERCIAL COMPANIES THAT ARE ALSO THEIR EMPLOYEES
}

\author{
Laura MANEA ${ }^{1}$
}

\begin{abstract}
From the logical and unitary interpretation of Law no. 31/1990 (art.72 and art.166), the liability of the administrators and auditors of the companies, who are at the same time their employees, is a civil liability - in the broad sense of the notion of civil law by applying the rules of the mandate. From the perspective of the patrimonial liability of the employees, according to the Labour Code, the ways of recovering the damage caused to the company to which you are subordinated in the employment relationship differ from the ways of recovering the damage in case of non-compliance of the mandate's limits. Analyzing the two types of liability, in the situation where the administrator also has an employment contract with the company, we conclude that the practical solution and in accordance with the concern of the legislator to prioritize the application of special law is to assess the conditions of liability of the administrator to the rules from the mandate provided by art. 2017-2024 Civil Code and Law no. 31/1990, and regarding the way of establishing the liability and recovering the damage, the provisions of art. 253-259 Labour Code.
\end{abstract}

Key words: employee, administrator, mandates, patrimonial liability, damage.

\section{Introduction}

A "Commercial company" is defined in the doctrine of Romania (Cărpenaru, S.D., 2000, p.147-148) as a group of persons legally coming together on the basis of a company contract and derive benefits of that of a legal personality and in which these associates agree to pool certain goods for the exercise of certain acts of trade in order to achieve and share the resulting benefits, while the commercial company by itself is an autonomous body, an abstract entity with its own distinct legal personality, rights and obligations.

Even if through its mode of formation there are differences in function, the legal form

\footnotetext{
${ }^{1}$ Transilvania University of Braşov, Faculty of Law, manea@unitbv.ro, corresponding author
} 
of the company chosen by its founders, aims of formation, in principle, all of them will have two aspects in common - the general meeting (of the associates or shareholders) and the administration of the company.

Though the General Body Meeting is a decision-making and regulatory body, the management of the company is ensured through its directors, some or all of whom will form a separate and permanent management body, which will have an executive role in implementing the decisions of the general meeting and will also be the organ for implementing decisions required for immediate operation. At the same time, the legal person (the company), through the decisions and actions of the administrator, exercises its rights and assumes its obligations(Piperea,Gh.2008, p.199), expresses its will, both internally (decisions taken with regard to its own employees, for example, or the application of certain internal policies), and especially externally, in relations with third parties.

Both the Civil Code (art.1913 et seq.) and Law no.31/1990 of the companies, provide both that any of the administrator may be associates or non-associates, natural or legal persons, Romanian or foreign, thus distinguishing between the representation of the company in the civil matters through a mandate holder (who can also be the associate) and the management of its daily business through the exclusive activity of the administrator. Taken individually the text of art.1913 para.4 of the Civil Code, it follows that administration through associates is the rule, they have a de facto and mutual mandate to administer from each other (Piperea,Gh. 2008, p.201), while administration through the administrator itself is the exception, where the text of the law calls and if the contract (i.e., the constitutive act)does not provide otherwise (i.e., in the absence of a stipulation to the contrary).

In companies with a large number of associates and investors, the decision-making power is concentrated in the hands of professional administrators, who in addition to the mandate of representing the legal person (the company)in civil matters, also establish the economic and development policy of the company, thus along with a mandate of representation, also have a mandate that takes into account the operations of internal management.

\section{The Legal Nature of the Relations between the Administrators and the Company}

A controversial issue of company law is also the analysis of the legal nature of the relations between the company and its manager, with different opinions depending on the different interpretation due to legislative changes over time.

Thus, in the classical conception of commercial law (XIXth century and early XXth century) the relations between the administrator and the company were considered relations arising from a contract of mandate through the common law. The basic idea of the theory of the mandate starts from the reality that the commercial company, being a collective legal entity, in order to be able to materialize its own will and to participate in the legal relations with third parties, is forced to act as the principal and delegate to some persons those attributes of management and legal representation (Calafus, 2007, p.8). 
Slowly, came the change in the definition of a legal person (the company), against the background of the development of the theory of company law at the beginning of the $X X$ th century and in effect the theory of the company's mandate received quite some criticism, that in the final doctrine (Munteanu, 2000, p.78) has been almost completely abandoned this theory.

The renunciation of the mandate theory was due to the lack of legal arguments that this theory offered solution to practical issues such as: who does the administrator represent as a trustee, the associates/ shareholders from whom he or she receives the power or the company on whose behalf the administrator participates in legal relations? And if, for the commission of a crime by the administrator, the company is to be liable as a principal (for the acts of the administrator) or directly (as if the act was of its own deed)? (Sova, Moraru, 2021, p.53-54).

Thus, given the complexity of the administrator's function (which, in addition to concluding legal acts on behalf of the company, also has the obligation to conclude material acts for the purpose of good management of the company's patrimony), but without forgetting the purpose of the company, it was argued that the theory of mandate gets absorbed by the theory of broader representation. Consequently, the relationship between the administrator and the company would no longer be a simple mandate, but a mandate similar to that of the guardian (Cărpenaru, 2000, p. 219), that is, the administrator-company relationship was justified on the theory of legal representation.

Currently dominating the Western doctrine, the theory of legal representation considers that the administrators, in the exercise of their functions, do not have the collective will of the associates, the administrators not being subject of law distinct from the commercial company, but are an integral part of it, and their powers does not arise from a contract concluded between them and the company (contract of mandates arising from the constitutive act), but from the law. This explains why the administrators have some powers that cannot be met in the person of the associates, such as: the power to stay in court on behalf of the company and the ability to engage the company through their acts (Șova, , Moraru, 2021, p. 54).

Other authors (Red, C., 2001, p.81), considered that the administrator is an organ through which the company carries out its activity, but this organicist theory was disavowed by the judicial practice that decided that the administrator cannot be an organ of the company, since he does not contribute to the formation of the collective will of the company, but to the execution of this will, since the administrator represents the company vis-à-vis third parties, leads the interests of the society, ensures the application of the law, the statutes and the execution of the deliberations of the general meeting, and in this framework works with full powers, and is accountable to the general body of the company.

Starting from the fact that the administrator carries out a continuous activity of the company and can also be remunerated for such activity, the theory that the legal relations between the administrator and the company could be exclusively an employment relationship based on an individual labor contact, was received with legal 
reservations because the weight of the administrator's position is given by the legal acts, and not by the material acts, as it happens in the case of the employment contract (Cărpenaru, 2014, p.223).

\subsection{Can the position of administrator be cumulated with the capacity of employee of the same company?}

Distinguishing according to the forms of the company (company with one or more shareholders, i.e. joint-stock company or limited liability company, for example), the answers and justifications to the question of the cumulation between the position of director and that of employee of the same company differ.

First of all, in the case of a company with a single associate, who is also the administrator, it is not lawful to merge an employment contract concluded with the company and the mandate of the administrator arising from the memorandum of association, because of the uniqueness of the person makes it impossible to materialise a subordination relationship specific to the employment relations between the employer and the employee.

In the case of joint stock companies, the merging of an employment contract of the employee-administrator and the prerogatives of administrator is forbidden by the letter of the law (art.137 ${ }^{1}$ of Law no.31/1990). For the case in which the employment contract was previously concluded to the nomination as administrator in the company, the law offers a solution: The text of the law expressly provides that during the fulfillment of the mandate, the administrators cannot conclude an employment contract with the company. If the administrators have been appointed from among the employees of the company, the individual employment contract is suspended for the duration of the mandate.

Per a contrario, to the imperative prohibition in art.137 1 of Law no.31/1990, in the case of limited liability companies with several associates, the quality of an administrator nominated through the articles of incorporation may be merged with the quality of an employee on the basis of an individual labor contract (contract to be signed by another administrator or associates representing the employer) with the role conferred by the articles of incorporation as a company administrator.

Starting from the management contract, specific especially to public institutions, for the exercise of other duties that exceed the mandate of representation as administrator, it is possible either to conclude an administration contract distinct from the duties of the articles of incorporation (contract that will have a civil contract regime), or to conclude a specific form of the employment contract in cumulation (part-time or fixed-term contract).

\section{Liability for Damages of the Administrator}

The administrators are liable to the company for the non-observance of the legal provisions (Law no.31/1990) regarding their duties according to art.148 para.1 of the 
Law no.31/1990, for the non-observance of the obligations on the basis of the mandate entrusted to them by the shareholders, by the articles of incorporation or through the general meeting, according to art.72 of the Law no.31/1990 (the provision as relating to joint stock companies managed in a unitary system are governed by art. $144^{2}$ paragraph 1 and for those managed in a two-tier system by art. $153^{8}$ paragraph 3 for companies managed in one-tier system). This liability is a contractual liability (it is a matter of noncompliance with the tasks received by the administrators according to the obligations contained in the mandate contract, separate contract or contained in the articles of incorporation).

If the administrators' actions result in an unlawful act or even of a crime, then we are in the presence of civil liability in tortuous civil liability or criminal liability as the case may be.

Law no. 31/1990 introduced for joint-stock companies the objective criterion of the good administrator, responsible for his management deeds, while in the case of limited liability companies the provisions of the common law through the mandate, which could be voluntary or remunerated.

As long as the administrator acts within the limits of his mandate, the trusteeadministrator does not answer with his own assets for the obligations he contracts on behalf of the principal/company (Vivante, 1928, p.96). If the administrator violates the duties conferred by the mandate and thus causes damage to the company, we are in the case of a tortuous civil liability, which is presumed committed according to art.220 of the Civil Code respectively by a liability action the members of the company's management bodies.

In the case of joint-stock companies, the administrators have delegated from their duties in turn to the directors or other employees, the liability of the administrators for their own deed will be doubled by the liability for the deed of others (the deed of the directors), in the context of the civil liability of the administrator has to supervise the directors/ employee on the way in which they perform the delegated duties (in this case, the recovery of the damage by the company from the director or employee on the basis of the patrimonial liability provided by the Labor Code, which will remove the liability of the administrator).

Regardless of the corporate form, in the case of multiple administrators, their liability is a joint and unitary, the de-solidarization being made according to rules that prove both their non-participation in the adoption of the decision, also to be considered in conjunction when the administrator's register an official protest against the decision and does not become party in implementing such decisions.

In all the cases analyzed above, the liability of the administrator is towards the company, and not towards the shareholders/ shareholders, because the mandate is received from the company, as a legal person, and not nominally from the shareholders. 


\subsection{Liability for damages of the administrator who is also an employee of the company he manages}

In the case of the cumulation of contracts that the administrator has with the company (the mandate contract cumulated with the individual employment contract), it will have to be distinguished and qualified as to whether the damage is caused as a result of the non-compliance with which particular contract. In case of non-observance of the obligations of the individual employment contract caused damage to the company, the specific liability of the labor law will be applied which is the patrimonial liability of the administrator-employee (Art.254 et seq. Labor Code), a specific type of contractual liability.

Thus, the facts and obligations deriving from the employment contract and the job description being distinguished from the general obligations of the administrator mandate, if the damage caused to the employing company is due to non-compliance with the obligations in the employment relationship, the administrator's first capacity as an employee, being applied exclusively the rules of patrimonial liability (Art.254-259 of the Labor Code regulates this type of liability different from the former material liability of the employees).

Starting from the valid existence and execution of the individual employment contract, for the patrimonial liability to be established for acts of the employee-administrator, the conditions similar to the tort liability must be met, namely the guilt of the employee, the harmful act and the causal link between the two.

In this case, unlike the solidarity of the administrators' liability for the non-observance of the mandate given by the associates, the patrimonial liability is a conjunct liability, the amount of each employee's liability being determined according to the extent to which the employee contributed to the occurrence of the damage, without counting in the case of the employee-administrator and his capacity as administrator. If the extent to which the damage to the employing company was contributed cannot be terminated, the liability of each employee shall be determined in proportion to his net salary from the date of the finding of the damage.

\section{Conclusion}

If the law or the articles of incorporation do not contain other provisions, the relations between the administrator and the company are subject, by analogy, to the rules of the mandate, with the specification that the mandate entrusted to the administrator has a contractual content, because the administrator's powers of attorney are given by the associates by their willful manifestation in this respect, by contractual clauses, materialized in the content of the articles of incorporation or in the decisions of the shareholders' meeting of the companies.

Given that the relations between the administrator and the company are regulated by 
the mandate contract, the administrator's mandate also has a legal character, thus distinguishing itself as a commercial legal mandate, with or without representation.

And thus, as we have proved above, the administrator is not a simple trustee (whose obligations would be exclusively contractual), but is the bearer of the collective will, the one who expresses and executes the collective will - a qualification that has important consequences related to the legal nature and the extent of legal liability, and furthermore being necessary to clarify if the administrator's liability is strictly a contractual one (mandate theory) or a tortious civil liability, as suggested by the regulations of Law no. 31/1990.

Concluding that a person may cumulate the capacity of administrator with that of an employee, being contracts of a different nature, but compatible (with the exception of the joint-stock company), the actions of the person concerned have different justification depending on whether the act was committed as the administrator, a trustee (representative) of the company on the basis of an apparent mandate, or as an employee of the company. The obligations and liability of the salaried administrator are determined based on the legal nature of the two contracts.

Thus, the administrator employee will be subject to the specific provisions of both the labor law in his quality as an employee and those specific to commercial law in terms of his capacity as administrator (Cărpenaru, 2000, p. 178; Șova, Moraru, 2021, p.55).

So, it seems to us that, although the two qualities may co-exist - administrator and an employee-they cannot determine the administrator-employee to be single entity, on whom single legal regime can apply, and so the law on the contractual liability for acts of representation based on the mandate will apply, along with those of the patrimonial liability of the employee for material acts committed by the administrator-employee.

\section{References}

Calafus, S. (2007). Natura juridică a raporturilor dintre administrator și societatea comercială pe acțiuni [The legal nature of the relationship between the administrator and the joint stock company]. Economica, no.3 (59), 8-11.

Cărpenaru, S.D. (2000). Drept comercial român [Romanian Commercial Law]. $3^{\text {rd }}$ Edition Bucharest: All Beck.

Cărpenaru, S.D. (2014). Tratat de drept comercial român [Romanian Commercial Law Treaty]. $4^{\text {th }}$ Edition. Bucharest: Universul Juridic.

Munteanu, E. (2000). Regimul juridic al administratorilor societăților comerciale [Legal status of company administrators]. Bucharest: All Beck.

Piperea, Gh. (2008) Drept comercial. Curs universitar [Commercial Law. University course]. Vol I. Bucharest: C.H. Beck.

Roșu, C. (2001). Natura juridică a raportului dintre administrator și societatea comercială [The legal nature of the relationship between administrator and the company]. Revista de Drept Comercial, no.4, 80-88. 
Șova, N., Moraru, I. (2021). Natura juridică a raporturilor dintre societatea comercială și administratorul acesteia [The legal nature of the relationship between the company and its administrator]. Revista Institutului Național al Justiției, no.1(56), 52-56.

Vivante, C. (1928). Principii de drept comercial. [Principles of Comercial Law] $37^{\text {th }}$ Edition. Bucharest: Cartea Românească Publishing. 